\title{
The Testament of Time - The Apocalypse of John and the recapitulatio of Time according to Giorgio Agamben
}

Giorgio Agamben is one of the most widely received and most important philosophers of our time. His philosophy can be understood as a continuation of Foucault's archaeology of knowledge. Accordingly, Agamben analyses the genesis of the essential occidental concepts, categories and constellations in the context of their political and noetic significance for the present age. Similar to Foucault, this endeavour includes an impetus that is critical of knowledge and society. Beyond Foucault, Agamben systematically deals with not only the influence of religious categories on the constitution of occidental power but also its subversive potential. Among Agamben's writings, his Homo Sacer project ${ }^{1}$, most of which has been translated into English by now, and his book The Time that Remains (Il tempo che resta) ${ }^{2}$ deserve special mention. In Il tempo che resta, Agamben particularly investigates apocalyptic thought and the correspondent concepts of time on the basis of an interpretation of Paul's Epistle to the Romans. Both aspects are key to a critique of systems of power and their structures of representation. This text also focusses on these questions. The first part of the article provides a definition of the position of current concepts of time, while the second traces key categories of Agamben, who responds to today's virtualisations with the concept of messianity. The third part will attempt to confront Agamben's change of perspective, which rests on observations from the Bible, wherein the problem of a critical vision of historical superpowers and their representation systems becomes the decisive criterion for an apocalypticisation of history.

1 Giorgio Agamben's Homo Sacer project consists of the following 9 volumes: Homo Sacer: Sovereign Power and Bare Life. [Homo sacer. Il potere sovrano e la nuda vita.]; State of Exception. Homo Sacer, II.1. [Stato di Eccezione. Homo sacer, II.1.]; Stasis: Civil War as a Political Paradigm. Homo Sacer, II.2. [Stasis. La guerra civile come paradigma politico. Homo sacer, II.2.]; The Sacrament of Language. An Archaeology of the Oath. Homo Sacer, II.3. [Il sacramento del linguaggio. Archeologia del giuramento. Homo sacer, II.3.]; The Kingdom and the Glory. For a Theological Genealogy of Economy and Government. Homo Sacer, II.2. [Il regno e la gloria. Per una genealogia teologica dell'economia e del governo. Homo sacer, II.2.]; Opus Dei. Archeologia dell'ufficio. Homo sacer, II.5; Remnants of Auschwitz. The Witness and the Archive Homo Sacer, III. [Quel che resta di Auschwitz. L'archivio e il testimone. Homo sacer, III.]; The Highest Poverty: Monastic Rules and Form-of-Life. [Altissima povertà. Regole monastiche e forma di vita. Homo sacer, IV.1.]; The Use of Bodies. [L'uso dei corpi. Homo sacer, IV.2.].

2 Agamben, The Time that Remains.

Note: The present essay is a revised version of the paper "Die Wahrnehmung des Freundes in der Messianität des Homo sacer," which has been translated by Brita Pohl and Christina Pössel and revised by Kurt Appel and Veronika Wieser.

ə Open Access. (C) 2020 Kurt Appel, published by De Gruyter. (๕) BY-Nc-ND This work is licensed under the Creative Commons Attribution-NonCommercial-NoDerivatives 4.0 License.

https://doi.org/10.1515/9783110597745-031 


\section{The Present between the Apocalypse and the Virtual}

\subsection{The Collapse of the Master Narratives and Subsequent New Narratives}

That motifs of the Apocalypse are invoked in a wide range of discussions and across disciplinary borders is not least due to the fact that, after the religious narratives that had constituted traditional symbolic orders have been replaced, their secular surrogates are also either in the process of disintegrating - like the one of a progress in the consciousness of freedom - or lead into nothingness, like the narrative of the approaching entropic death of the universe as an end point of evolution. ${ }^{3}$ In the mental landscapes marked by these losses there emerge, on the one hand, innumerable particular stories (sourcing their content in sports events, pop songs etc.) that all go hand in hand with a fragmenting subject. On the other hand, the fantasy novels of our time become manifest as new grand narratives to shape our global urban culture, their themes often resorting to pre-modern or medieval subjects. Star Wars, Game of Thrones, Ghost in the Shell, etc. not only pervade literature, film and video games, but, increasingly, the everyday lives of the urban populations of all nations and cultures. At present, people in the West no longer live from Sunday to Sunday, but from one series of Game of Thrones to the next. This means that, even more than the pop culture idols of the 1960s and 1970s, these stories shape all spheres of life and subliminally work as identity markers, neither against nor for modernity and its pathos of freedom, but alongside it.

\subsection{Apocalyptic Scenarios}

The new fantasy narratives both borrow extensively from, and redesign, religious and medieval motifs, in which apocalyptic scenarios enjoy a particular importance. While the traditional Christian theologies as expressions of the institutionalised religious denominations situate themselves in the "afterlife", the idea of the end of humanity is ever more prevalent in film (think, for instance, of Melancholia by Lars von Trier), literature (for example, The Road by Cormac McCarthy), and some of the aforementioned new master narratives (such as Game of Thrones) ${ }^{4}$. In a more or less coded manner, omnipresent figures like vampires, zombies, cyborgs, or mutants testify to the "end of time": the first two because they have survived their own death

3 Cf. Horn, Zukunft als Katastrophe, 7-43.

4 See Horn, Zukunft als Katastrophe, and Zolles, "Die Zeit apokalyptischer Repräsentation und ihre Aufhebung in Lars von Triers Film Melancholia." 
without being redeemed, the latter insofar as they prefigure the transition from humankind to a (potentially immortal) post-human age.

The traditional occidental historico-theological narrative - which may even define the "West" as such, and which has reached far into modernity - began with the eternity of God and of Heaven. It continued with cosmic history proper, shaped by humans, and found its conclusion in the anticipation of the Last Judgement. Its secular transformations conceived of the end of history either with utopian hope, or foresaw universal extinction. At present, it is the latter idea of all-embracing annihilation which shapes global culture. In the cycle of climate and environmental conferences, this apocalyptic undertone functions as a warning to politics and society that, should the present Western-capitalist lifestyle continue, global demise - at least of those forms of culture that humanity knows and regards as livable today will be inevitable. In addition, the demise of man is also regarded as an inevitable fact. Human beings and their native Earth are considered marginal phenomena in the unfathomable spaces of cosmogony and its attendant entropy. In the light of this consideration, the apocalyptic scenarios in the newly created fantasy worlds seem to be a kind of escapist or coping strategy in the face of the political, intellectual and scientific developments of our time.

\subsection{Virtual Worlds}

We might say that today, the threshold from moribund reality to a virtuality that is forgetful of death, or rather "undead", is being crossed ever more often. The virtual world renders times and spaces arbitrarily interchangeable and repeatable. The cyborg can be reloaded, and the virtual world of the internet can be reset any time. In the interactive transformations of the new narratives, the "subject" may adopt or abandon the persona of one or more avatars in the blink of an eye; what is more, the chosen "individuals" can continue running automatically, i.e. "by themselves". If the modern subject splits into a physical and a virtual (online) existence, the latter will survive the physical one. Heidegger's Being and Time was the epoch-making philosophical oeuvre of the twentieth century. ${ }^{5}$ Heidegger focused on mortality and finality, on the "Being toward Death" (Sein zum Tode) of Dasein. In the transition to the virtually determined times of the present, this scenario is changing. Our symbolic order is guided neither by a paradisiac eternity "post mortem" - whether disembodied or in a transfigured body - as laid down in traditional theology as the meaning of human existence, nor by the heroic "authentic" acceptance of finitude as propagated by the twentieth-century existentialists. In fact, what is beginning to show is rather a "post-mortal" continuing (i.e. a time that has left behind death as the end point) in a melancholy search for mortality, for the lost body and its time.

5 Heidegger, Sein und Zeit [Being and Time]. 
In this sense, we might speak of a (post-) apocalyptic world that has emerged from its own extinction. It is marked by the search for an irretrievably lost death. Our fear is no longer of finitude, but increasingly of the infinite. Fear is no longer focused on the end of history or its "thereafter", but on its irretrievable loss.

\section{On the aisthesis of the Messianic in Agamben's Homo Sacer Project}

\subsection{Theological Concepts and the Archaeology of Occidental Power}

Turning back to the quest for a philosophy of history, we need to acknowledge that the great teleological projects of modernity were all characterised by criticism of epistemology and society. Hegel's Phenomenology of Spirit is the first part of his system, but also a continuation of Kantian epistemology insofar as forms of knowledge are examined for their dynamic-genetic character, that is, understood as historically mediated. In the Marxist-influenced wake of Hegel, epistemology and social criticism increasingly combined with a deconstruction of the social dynamics of power. High points of this project were the writings of Walter Benjamin and Michel Foucault. At the intersection of these two thinkers, we find Giorgio Agamben.

Agamben is one of the most widely read and discussed philosophers of our time. His primary interest is a continuation of the archaeological-epistemological work of Foucault. More strongly than the latter, however, Agamben emphasises the profound, originatory influence of theological and apocalyptic-messianic concepts and ideas on the symbolic order of occidental thought that continues into the present. From his engagement with angelology through to his account of the genesis of the dogma of the Trinity, Agamben reconstructs the guiding principles of occidental thought on the basis of key Christian theologumena.

What needs to be mentioned in this context is Agamben's clear distinction between apocalypse and messianism. ${ }^{6}$ The former signifies the end of time, its transition into eternity. The latter, however, is marked by the time of the end, that is, by a kairos expressing the end of chronological time and its uniform progression without finality and sense. This distinction is complicated by the fact that biblical apocalypticism, with its most differentiated expression in the Revelation to John - contrary to the metaphysical reconfiguration of the biblical time in the schema of time and eternity since Late Antiquity - corresponds more to Agamben's messianic age, as examined in his book The Time that Remains (Il tempo che resta) ${ }^{7}$. This is why

6 Cf. Agamben, The Church and the Kingdom.

7 Cf. Agamben, The Time that Remains. 
Agamben's thoughts on messianity are very conducive to initiating an understanding of biblical apocalypticism and its relevance to contemporary social criticism.

\subsection{The Project of Messianity as an Alternative to the Camp}

As regards content, we first need to emphasise Agamben's radically critical demeanour with regard to the Western development of power. Agamben's key thesis is that the legal ${ }^{8}$ state of exception that was branded into European history in the concentration camp, represents a paradigm of the mental landscape of Europe. In Homo Sacer I, he writes:

One of the theses of the present inquiry is that in our age, the state of exception comes more and more to the foreground as the fundamental political structure and ultimately begins to become the rule. When our age tried to grant the unrealizable a permanent and visible localization, the result was the concentration camp. The camp - and not the prison - is the space that corresponds to this originary structure of the nomos. ${ }^{9}$

In his analyses, Agamben aims to trace the violent aspect of European history and to show how theological and metaphysical choices helped condition it. Auschwitz here serves as the constant catastrophic reference in which the intellectual history of Europe stares into its own abyss. In a manner of speaking, therefore, it represents the catastrophic face of an apocalyptic end of the world.

\subsection{Aisthesis of Reality and the Re-Writing of History}

The apocalypse, specifically the Revelation to John, understands itself as thought aiming to decode the character of history in order to unveil a corresponding vision of man. The present essay attempts to show that Agamben's work is also deeply marked by an "aisthesis of reality". His archaeology of power consists of exposing layer after layer in order to reveal a look at "bare man" - it is no coincidence that bareness is a key, recurring motif - and at that which conceals him, or what is concealed behind him. ${ }^{10}$ The question will be whether we will encounter an ultimate emptiness, or whether a perspective will emerge from which society, religion, art, philosophy, and above all history will have to be re-written. In doing so, Agamben cannot be appropriated by either theology or "secular" currents, because, as we will proceed to show, these alternatives no longer apply.

8 Below, we will need to point out that the figure of the state of exception transcends legal categories.

9 Agamben, Homo sacer, I.19

10 A reconstruction of the political dimension well worth reading is provided in a so-far unfortunately unpublished dissertation by Müller, "Das Paradigma der Schwelle." 


\subsection{The Sovereign, homo sacer, and Control of Bare Life}

In the first volume of his magnum opus, Homo Sacer, which is subtitled Sovereign Power and Bare Life, Agamben emphasises that "the entry of $z o \bar{e}$ into the sphere of the polis - the politicisation of bare life as such"11 is the decisive event of modernity. What constitutes modernity is the abstraction of human life from its social, legal and political embedment in order to establish the possibility of total control on the part of the one wielding power, i.e. the sovereign. Agamben uses two figures to illustrate his discourse: the sovereign and the homo sacer, who serves as the title of the entire project. Following Carl Schmitt, Agamben defines the sovereign as the one who is able to decide on the (legal) state of exception. He is therefore someone who defines the ultimate limits and power of law as he embodies the right to suspend the rule of law in order to secure the scope of power (including the scope of law which both implements and sustains power). Contrary to law, which always has lacunae, that is, areas to which the court's judgement cannot be applied, nothing may oppose the application of the sovereign verdict. If law secures power through the judgements of the courts, sovereign power manifests itself in the capacity to pass absolute and incontestable judgement. ${ }^{12}$ In accordance with his fundamental thesis of modernity as the control of bare life, Agamben offers a variation of the concept of sovereignty: "[...] in this sense, the production of bare life is the originary activity of sovereignty". ${ }^{13}$ Insofar as law is a codification of morality and thus of the social involvement of life, sovereignty consists of the possibility of absolute control over the individual without regard for its social relations. The sovereign can banish the individual from the legal sphere and from the social framework, completely refuse it social recognition, and thus reduce it to unprotected, bare life. Agamben therefore is able to say that the sovereign sphere is "the sphere in which it is permitted to kill without committing homicide". ${ }^{14}$

Before exploring the question of other possible applications of the figure of the state of exception, we shall discuss the counter-figure of the sovereign, the homo sacer. Referring to the Roman legal tradition, Agamben defines him as the one who "cannot be sacrificed yet may, nevertheless, be killed". ${ }^{15}$ The homo sacer is no longer part of the social fabric, he is, in medieval terminology, out-lawed. Being under the ban of the sovereign means to be banned from all legal and social relation-

11 Agamben, Home sacer, I.10.

12 Here it might be interesting to study parallels between Agamben and Hegel's Phenomenology of Spirit. In this latter work, too, the course of Modernity consists in the absolutisation of the structure of judgement, the highest form of which is to be found in the Terror of the Revolution and in Kantian Morals. Cf. Appel, “Nur in der Geschichte der Zeugen kann Gott in seinem Christus geschichtlich wahr werden'."

13 Agamben, Homo sacer, I.53.

14 Agamben, Homo sacer, I.53.

15 Agamben, Homo sacer, I.13. 
ships; excluded from the sphere of the living; the homo sacer is a living dead. In the antique world, he could therefore not be sacrificed, because, as a socially dead individual, he was unable to establish a link between the mundane world and the world of the gods.

For the following observations, we need to note that homo sacer is the anti-figure to the sovereign. "What unites the surviving devotee, homo sacer, and the sovereign in one single paradigm is that in each case we find ourselves confronted with a bare life that has been separated from its context [...]."16 The sovereign as well as homo sacer are figures without a social body, the "other" of the social world and its institutions.

The provocative aspect of Agamben's social criticism is the thesis that also and in particular in our present society, the "bare life is produced by a control mechanism", ${ }^{17}$ i.e. that Western society is this highly efficient mechanism, the innermost element of which is absolute control over human life. To begin with, Agamben thinks of the camp as the site of the production of bare life and absolute sovereignty over it. However, according to Agamben, the paradigm of absolute control has not been overcome. There are also currently sites of the production of bare life, for example places such as Guantanamo, refugee camps and banlieues, where life has been excluded from the social frameworks of the state. However, Agamben particularly links sovereign power in current society with medicine, which is both capable of designing future life and of determining its survival. ${ }^{18}$ In a deeper sense, the fact that the sovereign is not a person in the sense of a legal subject becomes apparent in that sovereignty no longer needs to be executed by a person; it consists of economic and bureaucratic processes that can produce survival in whole swathes of the world, or, on the other hand, set in motion anonymous social mechanisms to which the individual is totally subjected.

\subsection{Of the Power of "Making Survive" and of the Exclusion from the Sphere of Death}

At the outset I emphasised that we are currently witnessing an epochal transition from the mortal world to a world without death. Agamben's analysis of sovereign power can be linked to this observation; for it is possible that the melancholy search for the lost body and thus for mortality originates in the search for a sphere which is still able to elude the sovereign. Agamben himself does not define sovereignty only in the "traditional" manner, as the power over life and death, but also as the power

16 Agamben, Homo sacer, I.61.

17 Cf. Agamben, State of Exception. Homo sacer, II.1.

18 Agamben says that "the physician and the scientist move in the no-man's-land into which at one point the sovereign alone could penetrate”. See Agamben, Homo sacer, I.91. 
of "making survive", not only in the sense that the sovereign can grant survival, but also that he can enforce it. This means that in our time the power over death is transformed from the possibility of killing, hitherto the most extreme power, into the possibility of deferring death. The present homo sacer as the figure on the threshold between (social) life and death shifts from the exclusion from the sphere of life into the exclusion from the sphere of death.

Today's virtual worlds are therefore increasingly worlds in which the virtualised subject is separated from its own mortality, and in which cyberspace has usurped the function of the sovereign. Regarding the structure of time, the traditional time of salvation history and its secular offshoots still had a past and a future beyond their immediate grasp. In contrast, the unrestricted reproducibility and omnipresence of the internet forms a kind of permanent temporal state of exception. Virtual time, stripped of all direction, is the eternal Now without anything beyond itself, neither past nor future. In it, there is no asynchronicity; indeed, everything except the internet itself is present in the internet. It forms a ghostly sovereign and the container which comprises all events. As in any machine, events coincide with each other in such a way that there is no room for manoeuvre and no independent development of the individual moments; the events express a kind of absolute matrix that is no longer comprehensible, in which inside and outside, the real and the imaginary coincide.

\subsection{The Recovery of Man's Inoperativity}

\subsubsection{Agamben's Political Project}

The problem of virtuality is a key - though largely implicit - issue in Agamben's central work within the Homo Sacer project, The Kingdom and the Glory ("Il regno e la Gloria") ${ }^{19}$. Many of his other writings' motifs converge in this book, which aims to execute an archaeology of the genesis of the Western "governmental machine" - or rather of the proprium of Western politics and culture as such. According to Agamben, its basic coordinates lie in the tension between regno, that is, active government, and gloria, the inactive glory which forms the secret centre of power and which is not least tasked with legitimising and maintaining power. Therefore, every Western government needs to be legitimised by an externalised, sacral instance which cannot be represented directly by the governmental machine or any other institution or by the demos. The only function of this mysterious instance is to shroud the fact that the aim of the government lies in its own perpetualisation.

19 Agamben, Homo sacer, II.2. 
For this duality, Agamben cites examples from history ${ }^{20}$ and politics, adding an novel aspect of the sovereign: he is the character clothed in a glory that lies outside immediate political-administrative practice, and which today - as Agamben adds in an important aside - is above all allocated by the media. ${ }^{21}$ Agamben sees the central goal of his magnum opus in the task of opposing "the ingenuous emphasis on productivity and labour, [...] politics is here returned to its central inoperativity, that is, to that operation that amounts to rendering inoperative all human and divine works". 22 This is whence, in principle, all branches of Agamben's efforts derive; he sees "inoperativity as a properly human [...] praxis", man as the "sabbatical animal par excellence". ${ }^{23}$ The humanum is characterised by not being subject to the reign of instincts and the ends they entail; i.e. its ex-sistence precisely does not immediately coincide with the organisation of its life and survival. It is thus ultimately not subordinate to any functionality or external purpose. In other words: it is free - though Agamben deliberately avoids any emphasis of the term "freedom", probably because in the occidental tradition, the term has substantial action-theoretical connotations in the sense of the capability of self-beginning, the self-realisation of the subject, and of professional activity. Man will have to be made free of these functions by undergoing a desubjectification, which will be discussed in more detail below.

\subsubsection{The Eighth Day as a Festive Surplus of Time}

The Bible, as Agamben notices and explores in his book Nudities, ${ }^{24}$ presents the Sabbath as a "surplus" that cannot be made to serve a purpose. In its most profound meaning, the seventh day is neither a mere chronological add-on to the other days, nor simply an interruption of the six-day rhythm of work. Rather, it is the transcen-

20 Mainly following Kantorowicz' epoch-making work The King’s Two Bodies, published in 1957. 21 Agamben writes: "If the media are so important in modern democracies, this is the case not only because they enable the control and government of public opinion, but also and above all because they manage and dispense Glory [...]." See Agamben, Homo sacer II.2, xii. This means that the task accorded to religious authority, which consists in dispensing Glory, has passed on to the media. In this process, the separation of "government/kingdom" and "glory" is increasingly cancelled out. At this point, I would like to add another comment: Agamben has recently concluded his Homo Sacer project with the volume L'uso dei corpi. Homo sacer, IV. There the volume Stasis. La guerra civile come paradigma politico. Homo sacer, II.2 is listed as Homo sacer, II.2, the same as the volume The Kingdom and the Glory. It is hard to imagine that Agamben made a mistake in numbering them. Rather, two mutually non-exclusive interpretations suggest themselves: the first is to regard the volume Stasis as an appendix to The Kingdom and the Glory, the second in Stasis taking the place of The Kingdom and the Glory, the latter volume thus being quasi the "remainder" and centrepiece of the entire project.

22 Agamben, The Kingdom and the Glory, xiii.13

23 Agamben, The Kingdom and the Glory, xiii.293

24 Agamben, Nudities, 104-112. 
dent opening of time, which is structured and organised by work and the causalities linked to it. Through the surplus expressed by the Sabbath, time never forms a complete whole, but has an "outside", a rest that cannot be integrated.

In the Christian tradition, the Sabbath, the seventh day on which God "rested/ celebrated from all his work which God created and made" (Gen. 2:3), is transformed into Sunday. On the one hand, Sunday is the Christian equivalent to the Sabbath, that is, the day of interruption, of rest and festivity. On the other hand, it radicalises a moment already present in nuce in the Sabbath because it does not know any proper chronological "territory" but is radically a-chronological: as the eighth day, ${ }^{25}$ it coincides with day one, that is, with the day of original Creation and the first working day (and therefore symbol of active time). This implies two things: the eighth day may coincide with any other day, insofar as it is a working day; to a certain extent, it is the inner festive transformation of active time itself. Incidentally, until very recently, the Catholic liturgical tradition took this into account by including the Sunday liturgical formula also in weekday masses, thus precisely not opposing Sunday to the other days in a chronological sense. The second implication goes even deeper: the conflation of the eighth day with the day of the creation of the world indicates that the creation of the world takes place in the feast. In a temporal perspective, this draws a first line to messianity: messianic time is festive time, that is, time that no longer stands under the auspices of activities, external purposes or similar, that is not determined by the chronological chain of Being; instead, it festively expresses the openness of Being in relation to all necessities. ${ }^{26}$ In Kantian terminology, it is this un-reifiable sphere of freedom ("causality of freedom") which confronts the causality of nature, without being able to limit it "positively" in any way.

\subsubsection{The Dualism of Government and Glory, the Economy of Salvation and the Occidental Fracture between Being and Praxis}

From the axiom "to return politics to its central inoperativity" mentioned above, Agamben derives the most important definitions and analyses of his work The Kingdom and the Glory. Religion is situated in the sphere of glory, which finds its deepest expression in the celebration of the inoperativity of man, the (temporal) openness of Being as compared to any purely causal-chronological obligation. In Agamben's distinction between these two spheres, namely "kingdom/government" and "glory", the former stands for active work, that is, for the human accomplishments within the Chronos insofar as man is part of the realm of physical necessities. The second defines the "surplus", the unavailable transcendence of events that cannot be

25 Sunday is $6+1+1$, i.e. the addition of the Sabbath is doubled and thus solemnly confirmed.

26 Cf. also Bahr, Zeit der Muße - Zeit der Musen. 
caused nor classified, and that is granted to man as a gift to which he is summoned to respond.

Using the concept of the economy of salvation, Agamben demonstrates that in the European tradition of governance (including the separation between political/ state and clerical/church power) we can observe a deeply ambivalent development with regard to the relation between kingdom and glory. In its analysis, he mainly focuses on the Christian theological separation between an imminent and a salvation-economical Trinity. Thus in this separation the difference between God's being and God's action is revealed:

The divine being is not split [by the thought of creation and incarnation, i.e. the opposition between a world-transcendent Creator and a God of history] since the triplicity of which the Fathers speak is located on the level of the oikonomia, not ontology. The caesura that had to be averted at all costs on the level of being reemerges, however, as a fracture between God and his action, between ontology and praxis. ${ }^{27}$

According to Agamben, the fracture between Being and praxis that is expressed in this separation marks the end of the ancient world. ${ }^{28}$ Action cannot immediately be inferred from Being, but marks its own, separate sphere. This action therefore becomes independent of the Being and arises now from the conscious act of will - in which, so to speak, the subject gives birth to itself - and later takes over Being itself and becomes its paradigm..$^{29}$ As Agamben explains in Opus Dei, this means that all that is happening in the world is subject to the compulsion of always having to effectuate something ${ }^{30}$ and turns into a perpetuum mobile. It is particularly ironic that Christianity has never forgotten that such a perpetually moving machine, that is, the "idea of eternal government" is "truly infernal": ${ }^{31}$ only hell is captive to an eternal cycle of work.

It is essential that the spheres of Being (theology, gloria) and of action (economy, government) presuppose each other. Government has its most extreme plenitude of powers not where it legitimise itself by its ever-contingent action, but where its action produces glory from within itself.

27 Agamben, The Kingdom and the Glory, 53.

28 Agamben, The Kingdom and the Glory, 53-54.

29 Agamben particularly exemplifies this in Homo sacer, II.5. Opus Dei. Archeologia dell'ufficio. There, he says: "La fede cristiana è una mobilitazione dell'ontologia, in cui è in questione la trasformazione dell'essere in operatività" (Christian faith is a mobilisation of ontology, which poses the problem of the transformation of being into operativity). Cf. Agamben, Homo sacer, II.5, 72.

30 Cf. Agamben, Homo sacer, II.5, 102.

31 Agamben, The Kingdom and the Glory, 164. 
Government glorifies the Kingdom, and the Kingdom glorifies Government. But the center of the machine is empty, and glory is nothing but the splendor that emanates from this emptiness, the inexhaustible kabhod that at once reveals and veils the central vacuity of the machine. $^{32}$

Agamben emphasises that he understands man as the completely inoperative "Sabbatical animal par excellence". ${ }^{33}$ The paradox is that work can never stop because, in a way, it never completely fulfils man, because he can ultimately never be expressed through work. The separation of Being and praxis (in the sense of poiesis!) conveys that human Being never immediately passes into praxis, and that the latter is not contained in Being. However, the autonomy of the latter conceals that by itself, it comes to nothing, aims for nothingness, so to speak. The world as an absolute perpetuum mobile and perfectly connected causality of events would quite literally be "nothing"; its doxa (glory) would be the absolute meaningless void. It is precisely this emptiness of the paradigm of action that may also be veiled by glory. It establishes the illusiveness of legitimisation for an increasingly totalising government (in the sense of seamless poiesis). In other words: the paradigm of action attempts to circumvent its own meaninglessness by establishing a place, namely the transcendent sovereignty of "glory", which evades this paradigm while implementing it at the same time.

In this way, the government is solely legitimised by the glorification of the "Other" (glory), and the only function of this "Other" is this legitimisation. Thus in Agamben we ought to distinguish a yet-to-be-explored messianic doxology from an economic doxology. ${ }^{34}$ This, however, opens up possibilities of misinterpretation, because the (economic) doxology, as a core component of negative theology - in which God as the complete Other can only be met with encomium (as Agamben presents it in his angelology insofar as the angels permanently convert operativity into encomium) has "the function of cover and serves to found a governmental hierarchy". ${ }^{35}$ Regarding government, therefore, the sovereign power of glory is the "remainder that poses itself as the whole that infinitely subtracts itself from itself" ${ }^{36}$ It is therefore effectively the hidden veiling that makes us forget that the whole realm of praxis or poiesis is rendered inoperative (rendere inoperoso) in man. While there is an awareness in doxology that the dispositive of action is not the ultimate reality of man, this, paradoxically, continually turns into its opposite, becoming subject by

32 Agamben, The Kingdom and the Glory, 211.

33 Agamben, The Kingdom and the Glory, 246.

34 Agamben does not explicitly use these terms, but in substance.

35 Agamben, The Kingdom and the Glory, 155.

36 Agamben, The Kingdom and the Glory, 99. 
action, because the subject glorifies its own action in the glorification of the Other, without admitting to do so even to itself. ${ }^{37}$

As regards time, it needs to be emphasised that eternity as a place of glorification is precisely not messianic time, as Agamben shows in another important work, The Time that Remains, it is only the mirror of working time and its legitimising point. We might say that the biblical model, according to which the working days were created for the sake of the seventh day and only derive their meaning from it, is inverted in such a way that timeless eternity legitimises the immanent progress of the machine of work. But how can we distinguish the Messianic from its perverted form? In order to explore this, we need to consider the concept of dignity and its problems.

\subsection{Dignity, Shame, and Speechlessness with regard to the homo sacer}

Dignity is a key term of the Western tradition, and the concept of human dignity guides much of current ethical discourse. In The Kingdom and the Glory, Agamben linked glory closely to the dignity (dignitas) of the sovereign; the latter represented both the starting point and product of glorification. It thus marks a sphere which seems to elude human manipulation, and essentially forms that additional space in which the definition of the world as a mere nexus of means-and-ends relations - in Kantian terms, the "causality from nature" - is left behind.

The thoughts explored in the preceding section suggest that this approach to dignity will not be Agamben's last word on the matter. However, we need to emphasise that dignity has to be regarded as a founding figure of religious interpretations of Being as well as a cornerstone of secular ethics. The idea that man, with any of his words, gestures and expressions, reaches beyond himself as a mere creature of nature (animal) and beyond any determinable meaning - which is why there will never be a finished lexicon - and does not coincide with himself in a purely immanent manner (like a machine that only signifies its own set operations and is unable to distance itself in the least from this functionality), served as a signpost to a transcendent expansion of purely immanent concepts of work and causality. This is manifest in its earliest secularised form in Kantian ethics, according to which man not only has an exchange value but a dignity elevated above any calculable value. ${ }^{38}$ More recently, it manifests in the concept of human rights which are regarded as non-negotiable because of the dignity of man.

37 Here, too, we may identify a close resemblance between the analyses of Agamben and of Hegel, in the unhappy consciousness, in which the subject thinks it works for the glory of God but in reality appropriates this glory himself. Cf. Hegel, Phenomenology of Spirit.

38 Cf. Kant, Groundwork for the Metaphysics of Morals, 43. 
Of course, Agamben does not reduce man to a perpetually operating, incessantly causally determined machine; nevertheless, he leaves room for a suspicion that the concept of dignity - like the one of glorification - also conceals something. There is particular scope for this suspicion in the third part of Homo Sacer in which he attempts an analysis of Auschwitz. ${ }^{39}$

Auschwitz, according to Agamben, defines an ethical aporia; it is "the site in which it is not decent to remain decent, in which those who believed themselves to preserve their dignity and self-respect experience shame with respect to those who did not". ${ }^{40}$ What is this suggested indignity of dignified behaviour in a borderline situation in which sovereign power reduces man, layer by layer, to his bare biological life, which may, if necessary, be "eclipsed"? The second question regards what exactly is expressed by the feeling of shame, of which already the young Hegel said that it does not express "fear for one's own", but fear "in the face of one's own selfcenteredness". ${ }^{41}$

Agamben makes a momentous observation:

\begin{abstract}
In certain places and situations, dignity is out of place. The lover, for example, can be anything except 'dignified', just as it is impossible to make love while keeping one's dignity. [...] There are good reasons for this impossibility of reconciling love and dignity. Both in the case of legal dignitas and in its moral transposition, dignity is something autonomous with respect to the existence of its bearer, an interior model or an external image to which he must conform and which must be preserved at all costs. But in extreme situations - and love, in its own way, is also an extreme situation - it is not possible to maintain even the slightest distance between real person and model, between life and norm. ${ }^{42}$
\end{abstract}

Dignity duplicates man by setting aside a (sacral) sphere in which the subject finds its last refuge, which seems to withdraw it from simple availability. This constructs a symbolic order which opens up a space between mere nature (bare life) and its mental "rewriting" and relecture, which in a way translates physis into language and produces a permanent surplus of meaning of the word as compared to the immediate practice of life, which therefore can never be recovered by man. ${ }^{43}$ The atrocious message of the camp, however, is that "there is still life in the most extreme degradation". 44

The purpose of torture is the un-dignifying of a person by reducing them to a mere piece of nature. The concentration camp "produced" such degraded "bare" life, which was no longer clothed in dignity, and which in the camp was described

39 Agamben, Homo sacer, III.

40 Agamben, Homo sacer, III, 60.

41 Hegel, On Christianity, 306.

42 Agamben, Homo sacer, III, 68-69.

43 Agamben here follows Lévi-Strauss when talking about a surplus of signification vis-à-vis the signified, i.e. a non-correspondence between the sign and the signified, from which arises the freedom of logos as compared to physis. Cf. Agamben, Homo sacer, II.3, 67-68.

44 Agamben, Homo sacer, III, 69. 
as the Muselmann. The latter stands at the threshold "between man and nonman", ${ }^{45}$ not least because he is deprived of his subject function, because he cannot, so to speak, bear witness for himself.

The Muselmann as an expression of utter degradation thus defines the extreme situation that Agamben also envisages for love, namely the radical disappearance of the distance between the subject and its model (which is expressed by dignity). The subjectification of our nature and denotative language (defining and explaining the world) cultivate a permanent construction of this distance, the permanent construction of one's own model in order to be able to liberate oneself from the immediate acts and attributions of life. This also addresses the crucial moment of Hegel's thought, in which religion is situated in opposition to speculative knowledge. Contrary to a frequent assumption, what is at issue is precisely not the abolition of the sensual dimension of knowledge, but rather the structure of knowledge which segregates the Absolute (the absolute subject) into a separate sphere in order to keep it "pure" and inviolable by avoiding exposing it (and therefore the subject situating itself in it) to any risk.

Agamben, by contrast, emphasises that love risks its own model and is prepared to expose itself to the "Other". The crucial aspect of his argument lies in the analysis of shame. We have already mentioned that in Hegel's early works, shame is defined as fear of one's Own. Referring to Levinas, Agamben takes a similar direction:

[Shame] does not derive [...] from the consciousness of an imperfection or a lack in our being from which we take a distance. On the contrary, shame is grounded in our being's incapacity to move away and break from itself. [...] To be ashamed means to be consigned to something that cannot be assumed. [...] In shame, the subject thus has no other content than its own desubjectification; it becomes witness to its own disorder, its own oblivion as a subject. ${ }^{46}$

In these phrases Agamben approaches the question of what remains when dignity and glory no longer represent the transcendent reference points of our aisthesis. One answer might be that the result would be a world without doxa, an example of which Agamben sees in the depilated bodies of fashion models and porn stars. ${ }^{47}$ However, this view arises when images have achieved complete autonomy from any reality and show a perfect illusory world.

By contrast, shame is not about the "whereabouts" of the subject in any image, for example, in the sense of a subject being ashamed in a situation which contradicts the moral image that the subject has constructed for itself. Instead, it is about a radical de(con)struction of the subject. The subject in a way becomes a witness of itself as a "non-human" which can no longer be represented, delineated and evaluated. Agamben does not coin this expression in order to record that there might be

45 Agamben, Homo sacer, III, 47.

46 Agamben, Homo sacer, III, 105-106.

47 Agamben, Nudities, 97. 
human beings who have become so dehumanised due to abuse, torture and banishment that there remains nothing of humanum. Rather, "non-human" is the sphere in which any linguistic or conceptual visualisation reaches its limits, the "remainder" that is left when, with dignity, the transcendent and thus "highest" reference of the human being has been violated.

Possibly the most important idea of Agamben is that, ultimately, the subject can be decoded neither as an indestructible substance in the sense of metaphysics nor as a transcendental companion in the sense of Kant, nor as a carrier of moral judgements and actions. Subjectivity, by contrast, is encountered in the testimony of a desubjectification: "human beings are human insofar as they bear witness to the inhuman [that is, to non-human]."48 It is precisely at the site where any internal or external modelling is shattered that subjectivity emerges. Subjectivity thus generates itself in the testimony for the speechless, for the non-figure, for the one who is removed from any noetic or practical control, for the homo sacer. Homo sacer thus gains a new inflection: so far, he only was the one who was under the spell of social and symbolic systems of reference; now, in his complete lack of images, he becomes the starting point of a becoming-human of the one bearing testimony to him. With a theological twist, we might say that homo sacer, insofar as he is testified as such and insofar as there is faithfulness to this experience, "heralds" the arrival of the messianic subject, which experiences in this testimony, that is, in his own subjectification, eo ipso a desubjectification: it is not "I" who lives, "but Christ liveth in me" (Gal. 2:20). ${ }^{49}$

However, it is not only the conceptual world that is shattered by the homo sacer, but also, as Agamben states in The Time that Remains, the denotative function of the language of depicting Being. This sublation of denotative language has a notable parallel in the world of love: "[Love] is not a world of predicates [...] but a world of indivisible events, in which I do not judge, nor do I believe that the snow is white and the sun is warm, but I am transported and displaced in the snow's-beingwhite and in the sun's-being-warm." ${ }^{50}$ Modern man tends to enter into a world of judgments and statements which they use to orient themselves. In this manner (as Agamben also writes in the conclusion to his Homo Sacer project, L'uso dei corpi), ${ }^{51}$ language becomes the decisive moment of Being. We might say that language and Being form a zone of indiscernibility. In contrast, the messianic moment emerges where language in its denotative and judging functions is rendered inoperative (rendere inoperoso). Agamben refers to an "absolute nearness of the word" 52 to which

\footnotetext{
48 Agamben, Homo sacer III, 121.

49 It is important here that in this sentence, there is also a passage from Christ as a designation of the Messiah to Christ as a proper name. For here there is no longer the structure of a judgment, but only the name that invalidates all judgments and previous images.

50 Agamben, The Time that Remains, 129.

51 Cf. Agamben, Homo sacer, IV.2, 155-178.

52 Agamben, The Time that Remains, 136.
} 
the apostle Paul bears witness. In it, the word no longer functions as a predicative judgment, not even as a performative self-expression of the speaker, but remains in a dialectic of subjectification and desubjectification insofar as an event is denoted which once more systematically renders inoperative all meanings and forms of expression, and which, precisely in this gesture, "bears witness to what, unexpressed and insignificant, remains in use forever [...]."53

Returning to one of the fundamental theorems of Agamben's philosophical project, in which messianity is expressed by the fact that "politics is [...] returned to its central inoperativity" by "rendering inoperative all human and divine works", ${ }^{4}$ this rendere inoperoso becomes apparent first and foremost in a radical shift of perspective. The world is separated from its linguistic and conceptual accoutrements and images. And the last instance - "God" - which in its glory consists in the praise of those acclaiming it, brings forth "a nudity" "that theology absolutely does not want to see". ${ }^{55}$ This leads to an absolute experience and a last encounter between the world and God. As Agamben describes this in his book The Coming Community: "God is in every thing as the place in which every thing is" 56 and "[what] is properly divine is that the world does not reveal God". ${ }^{57}$ Messianity therein reveals itself as radical immanence and devaluation of all models which lie between the human being and the experience of the singular, the exposed, or, in Agamben's words: the remainder in which alone truth becomes visible. ${ }^{58}$

\section{Ecce homo, or the Conflation of Sovereign and homo sacer}

\subsection{The Gift of Vulnerability}

What is striking about the first account of creation at the beginning of the Bible is that several times God sees that what he has done is good. This formula reoccurs in Genesis 1:31, referring to the entire work of creation, which has come to a good, if as the seventh day demonstrates - open conclusion: "God saw every thing that He had made, and, behold, it was very good." Oddly, of what exactly the goodness of His creation consists is rarely explored. An interesting perspective is opened up by

53 Agamben, The Time that Remains, 137.

54 Agamben, The Kingdom and the Glory, xiii.

55 Agamben, The Kingdom and the Glory, 221.

56 Agamben, The Coming Community, 14.

57 Agamben, The Coming Community, 90.

58 Thoughts of a very similar structure can be identified in Hegel, in Musil's Man Without Qualities, and in Hölderlin. Cf. Appel, “Gott - Mensch - Zeit;” Deibl, "Vom Namen Gottes und der Eröffnung neuer Sprachsäume.” 
the first mention "that it was good", in Genesis 1:10, because this follows not immediately after the first act of creation, but only after the third. Three separations precede this statement: of light from darkness, of heaven from earth, and of land and sea. The three also implicitly separate the sphere of the living from the sphere of the dead/the immortal from each other. In particular the second separation, the delimitation of heaven, precludes that immortal things may interfere with the terrestrial "one-day" with its rhythm of evening (time doomed to death) - night (death) morning (new creation). The fragility of the relation between the immortal celestial and the mortal terrestrial is demonstrated not least in Genesis 6:1-4 (or Gen. 6:1-5), when the (celestial, immortal) sons of God descend to earth to procerate with the daughters of men and have to be restrained by God.

In this article's first part, I referred to the seventh day, which transcends Creation. It is both the festive beginning and end of the world, forming a sphere that is neither included in chronological time nor external to it. In answer to the question of what is being celebrated, the subsequent sequences offer indications that it is the vulnerability, the "not-being-God" of Creation. In contrast, the fall of man consists of his endeavour to gain seamless control over Being, not least in the form of absolute knowledge, which, in its totality, leaves us only with a void of meaning, i.e. “evil”. 'Before' the fall, man is in a sense endowed with a fragility which opens his path to the tree of life. In the seamlessness of his claim to knowledge and power, however, which also includes the claim to access the world of the Gods (as we shall see below), he blocks his own path to life.

The extent to which the theme of death is at the heart of the beginning of Genesis is apparent in the discourse between Eve and the serpent. It culminates in the latter's statement: "Ye shall not surely die; for God doth know that in the day ye eat thereof, then your eyes shall be opened, and ye shall be as gods, knowing good and evil." (Gen. 3:4-5). To read the statement of the serpent, the personification of desire, simply as a lie, is too simplistic: after all, its second part, the "opening of the eyes”, has come true. Indeed, the serpent's statement represents the key challenge, in a way the wager between God and man that pervades the whole Bible: will humanity manage to usurp immortality for itself and thus breach the separation between the human and the divine world, or will the human pretence to omnipotence remain limited by that separation? The wager is, on the part of humanity, its death, and on the part of God, his being God as the limit to human self-assertion. ${ }^{59}$ The subsequent events of the Bible affirm and develop this direction of inquiry: Cain, the man whom Eve has conceived (Gen. 4:1), is as the first-born the guarantor of a symbolic immortality of Adam, who continues to live in his image. On the other hand, Abel, whose side God takes, is, as his name implies, superfluous, an insubstantial "breath" as transient as a breeze. Later, the great human endeavour of mak-

59 Could man usurp immortality, he would finally take the place of God, and God could no longer fulfil his divine function, namely protecting man from himself. 
ing a name for oneself, that is, of gaining immortality, follows the genealogy of Cain and reveals the genesis of cities (and their structures of power), of the military and of culture (Gen. 4:19-22).

To return to the initial question regarding the "goodness" of the world, it should be noted that it is good precisely where it is not clad in its own pretence to power and its own self-assurance, but where it dons the "robe of light" of vulnerability, accessibility, and mortality. The openness of this fragility is the precondition to relations and compassion, which is celebrated and brought to mind on the seventh day.

\subsection{Ecce homo}

The vulnerable as a hermeneutic key to history is also raised in other pivotal places in the Bible. In Genesis, Chapter 18, $\mathrm{YHWH}^{60}$ allows himself to be seen near the oaks of Mamre, namely by revealing himself in the hospitable reception by Abraham. ${ }^{61}$ The fact that this revelation occurs in the figure of a guest can hardly be a coincidence, for YHWH repeatedly appears as a guest later, whether in the Tent of Meeting or in Jesus of Nazareth's visits to many houses. The guest withdrawn from the security of his own home is a figure which neither can be appropriated, nor does it designate the wholly other. Rather, the guest is situated at the threshold between one's own and the foreign, between the centre and the periphery. The guest is never "at home" but always by the other; he does he exist "in himself", but only as someone received by the other. However, the guest does not emanate from the host's will, but is in fact received. What is at issue in the pivotal biblical revelation (Exod. 32:30-34:9), which is linked to Genesis 18 through various key words, ${ }^{62}$ is the visibility of YHWH to Moses. Moses will receive a revelation of the name of YHWH as a merciful God in the passage of his glory. What is emphasised, however, is that man "does not see YHWH (or rather his face) and live". ${ }^{63} \mathrm{~A}$ direct approach to the Absolute (and its appropriation, implicit in the approach) is thus excluded in the text; in fact, it would result in death.

The question of the vision of the Divine returns to the centre of attention at the end of the Bible, in the Johannine writings ${ }^{64}$ which conclude both the Gospels and

\footnotetext{
60 YHWH designates the Biblical name of God (literally probably "I am the one who will have proved himself as being” ...), which was never vocalised and therefore cannot be pronounced. 61 On the meaning of the guest, cf. the outstanding book by Bahr, Die Sprache des Gastes. 62 Keywords from Gen 18 taken up in Ex 32:30-34 are e.g. "finding favour/grace in thy sight”, "pass on", "way of YHWH”, "know".

63 Cf. Dohmen, Exodus 19-40 (HThKAT), 316-360. Cf. also Schwienhorst-Schönberger, "Sehen im Nicht-Sehen. Mose auf dem Berg Sinai."

64 These include the Gospel of John, the three letters of John, and the Revelation to John (Apocalypse) as the last biblical book.
} 
the Bible as a whole. Indeed, the "seeing" of the "Kyrios" 65 becomes the pivotal guiding thought. In the prologue to the Gospel of John, a complex dialectic becomes apparent: on the one hand, it emphasises that "no man hath seen God at any time" (John 1:18), on the other hand, it refers to the one who "dwelt among us (and we beheld His glory, the glory as of the only Begotten of the Father), He hath declared Him" (John 1:14-18). Just as Exodus 32:30-34:9 affirms that God can only be experienced in mercy - in the two dimensions of healing and absolution - the prologue to the Gospel of John also makes clear that one cannot directly gaze at the "Father". Indeed, the significance of Jesus as the Crucified - that is, as homo sacer - is to be the interpreting signum of the "Father".

Of particular importance is John 1:35-39a:

The next day John [the Baptist] was there, and two of his disciples; And looking upon Jesus as he walked, he saith, Behold the Lamb of God! And the two disciples heard him speak, and they followed Jesus. Then Jesus turned, and saw them following, and saith unto them, What seek ye? They said unto him, Rabbi, (which is to say, being interpreted, Master,) where dwellest thou? He saith unto them, Come and see. They came and saw where he dwelt $[. . .]^{66}$

The meaning of the vision of the Lamb of God, namely a farewell to all self-representation of power which will have determined our history, is made clear in the Revelation to John (Apocalypse) in many inflections and emotional landscapes: it is the slaughtered Lamb of God which unveils (apokalyptein) the seal of history. The quotation above is initially more "muted": while one of the two disciples of John who are invited to see is identified as one of the future "twelve" apostles, namely Andrew (John 1:40), the other remains unnamed and is therefore intended for the identification of the reader. Thus we may argue that Jesus, John the Baptist, Andrew and the reader of the Gospel meet in this excerpt. In the Gospel of John, John the Baptist is the representative of the Old Testament prophets and therefore symbolises the Gospel of John's argument that the books of the Old Testament (that is, the logos that is at the beginning) bear witness to Jesus and find new embodiment in his flesh. The logos that is at the beginning is not only the Word in general but the text which receives the world and vice versa, and in which Jesus is embodied.

This shows that the testimony of John the Baptist and his disciples (including the reader of the Gospel) begins with a reinterpretation of the corpus of the entire Tanakh (the Hebrew bible), which, however, presupposes a special reading according to the corresponding view of Jesus. The quotation above expresses a very particular motion: it starts with the testimony of John (and thus of the Old Testament text), which the readers may enter through identification with his disciples, and continues with the question of the dwelling of the one who baptises with the Holy

65 In the Septuaginta, i.e. the Greek version of the Bible, YHWH, the Hebrew name of God, was rendered as the title "Kyrios" (Lord).

66 The translation used is the King James Version. 
Ghost (that is, Jesus: see John 1:33) and thus attempts a new reinterpretation of the scripture. The invitation to go with Jesus and to see where he dwells thus expresses the invitation to arrive at a vision of Jesus by means of the text of the Gospel that allows for a relecture of the Scripture and of the name of God YHWH.

This text as the genuine dwelling of Jesus subsequently contains seven signs in which Jesus interprets YHWH, the name of God (I AM ...). A key passage is the raising of Lazarus in which Jesus becomes manifest as "the life" (John 14:6). This seems slightly at odds with the fact that in his last great speech of instruction to the disciples/readers (John 14-17), Jesus says that they will accomplish much greater works than he himself "because I go unto My Father" (John 14:12). Jesus going to the Father withdraws his body from the disciples' immediate access. However, this results not only in a negative change in the relation to Jesus as the interpreter of God, but also signifies a new expansion of His body which results from His withdrawal. In a sense, the body of Jesus spreads out between the two poles of heaven and earth, and it is precisely in this in-between space that the Gospel is located, a text which those following Jesus can don in order to see him properly. The greater sign the disciples are promised refers to the mission of the Paraclete, the Spirit (John 14:17). In it, a vision is disclosed which results in the composition of the Gospel of John, or rather of the Johannine writings. The greatest sign is therefore a messianic corpus of texts obtained by the mission of the spirit in which the body of Jesus is transposed and which bears witness to Jesus as homo sacer.

The vision of Jesus finds its immediate expression in joyful love (John 15:12) and in friendship (John 15:15) to which the readers are summoned. In the Gospel of John itself, there is, in addition to the initial call to see Jesus ("Behold the Lamb of God!", repeated twice by the Baptist) in John 1:29.36, another summons at the end of the Gospel, contained in the description of the trial against Jesus:

Pilate therefore went forth again, and saith unto them, Behold, I bring him forth to you, that ye may know that I find no fault in him. Then came Jesus forth, wearing the crown of thorns and the purple robe. And he saith unto them, Behold the man! (John 19:4-5)

Strangely enough, in most translations ${ }^{67}$ the Ecce homo is ascribed to Pilate, though this attribution seems unlikely (even though not impossible) both grammatically and theologically. ${ }^{68}$ It seems more plausible that Jesus is the speaking subject. At the start, John bears witness to Jesus, and at the end of the Gospel it is Jesus himself who has "greater witness than that of John" (John 5:36). Jesus challenges the reader of the Gospel to open himself to seeing the man: namely the wrongfully tortured and ridiculed man, the homo sacer who is excluded from the sphere of law. In this gaze upon the bare body, which has lost all cultural or status-oriented attributes, which

67 Not, however, the Vulgate!

68 I owe this reference - and so much more in my reading of the Bible - to Roberto Vignolo, professor of Bible studies at the Facoltà teologica dell'Italia Settentrionale. 
holds nothing back either aesthetically or regarding its knowledge, God - in biblical terms - takes up His dwelling (i.e. He receives the right to hospitality). Taking up Agamben's words, we may refer to a "singularity without identity" 69 which recognises "what is properly divine [in the fact that] the world does not reveal God". ${ }^{70}$

The Gospel of John thus through seven signs (from the wedding at Cana to the raising of Lazarus) approaches YHWH, the name of God, finding its climax in Jesus' last personal statement, ecce homo. Its crucial messianic content is that in this scene, the two figures of the homo sacer (in his absolute vulnerability and homelessness) and the divine sovereign directly coincide or - as Agamben would have it form a zone of indiscernability. Jesus is the one testified as well as the testimony (cf. John 5:34) and thus becomes - in paradoxical terms - the subject of the testimony of a desubjectification.

The last text of the biblical Canon, the Revelation to John, also revolves around this kind of subjectification - which is not at home in itself - in which the "Ecce homo" of the Gospel is historico-theoretically developed and substantiated.

\subsection{The Revelation to John and the Last Meeting of Mankind}

The Revelation to John, which for centuries has been interpreted metaphysically, ${ }^{71}$ is more subtle than has often been perceived, in particular in its historico-philosophical propositions. It does not simply follow the pattern of an appointment with eternity as the end of history. Unlike any other biblical book, Revelation quotes a wealth of other parts of this library. It forms a collage of quotes which is placed at the end of the Bible not only in terms of its theme, but which also recapitulates the complete canon. However, in contrast to other biblical (and New Testament) scriptures that refer to each other, there are no direct quotes. Instead, all quotes appear in a singularly fractured and displaced manner, as though direct access to history was impossible. ${ }^{72}$

The impression of shifts, displacements, of a re-creatio of given texts is radicalised when we focus on the use of language, and more precisely the grammar, of this recapitulating book of the Bible. The author writes in a semiticising Greek; his vocabulary is extensive and he has a fluent command of Greek. This renders his severe grammatical errors all the more bizarre; however, when considered in a systematic manner, these mostly occur in the context of God's appearances (e.g.

69 Agamben, The Coming Community, 64.

70 Cf. Agamben, The Coming Community, 90.

71 An exceptional presentation of paradigmatic interpretations of the Revelation to John is provided by Zolles, Die symbolische Macht der Apokalypse.

72 Cf. Paulsen, "Zu Sprache und Stil des Johannes-Evangeliums." 
Rev. 1:4-6: apo with nominative!). ${ }^{73}$ The text therefore shows in a striking way that, confronted with the last word of God, language shatters. Or - to use Agamben's words - in messianic time the denotative and judging (identifying) character of language is rendered inoperative.

Another aspect that needs to be emphasised is the fact that the text presents seven beatitudes. The Revelation to John therefore is no sinister text threatening the coming destruction of the world, but - at least to its addressees - a message of good news (evangelium) and the definitive relecture of the Sermon on the Mount! We need to note the significance of the number "seven" that characterises this book (seven churches as addressees, seven seals, seven trumpets, seven bowls, seven visions which prepare the final vision of a new heaven and a new earth in Rev 19-20). The number "seven" echoes the programmatic introduction of the Bible (creation in seven days). Accordingly, the style of the Revelation to John is characterised by a solemn liturgics. Throughout the book - or rather, we should say: throughout the letter, as the last book of the Bible is a sermon by letter - a heavenly liturgics is enacted which invalidates history (for which Agamben coins the happy phrase rendere inoperoso, to render inoperative).

The decisive question with significance also for the hermeneutics of history (and perhaps also of interest to medievalists) concerns that which "is rendered inoperative": the human history of violence and its representations. The last book of the Bible, the letter of John, recapitulates the entire biblical history and in it the complete history of humanity (represented by "Egypt”, “Assyria”, "Babylon”, "Persia”, the Empires of the Diadochi and Rome); in this recapitulation, it finds its decisive hermeneutics and reinterpretation. We have to emphasise that the addressees of the letter/the Revelation are the followers of the mortally wounded Lamb of God (the crucified Messiah to whom the ecce homo refers), who is able to open the seal of history.

Before the eyes of these addressees unfolds the successive displacement of all representations of the ruling and violent powers of history, both linguistically - see the shattering of the ruling grammar! - and symbolically: "throne”, "trade”, "urban life", "armament" etc. are also rendered inoperative. At the end of the letter of John, after the final visions (including the disappearance of the history of violence in the lake of fire) the texts moves to focus on the new heaven and the new earth (including the arrival of the City of Jerusalem, the gates of which are now always open), but almost immediately turns into an audition and a solemn liturgy (celebrated by the victims of history) - and ends, as the last word and the last appointment of history, in an amicable blessing for all.

In the sign of the cross, a multifaceted imagery which invokes the entire contemporary visual repertory is employed to separate power from its visual and lin-

73 Cf. Paulsen, “Zu Sprache und Stil des Johannes-Evangeliums.” Also Biguzzi, Apocalisse nuova version, introduzioine e commento. 
guistic representations, and the last appointment which remains is the one with the open wound of the Lamb which, at the end, is symbolised by a paradisiac tree of life - showing that the tree of life in the Garden of Eden is nothing but the self-exposing vulnerability of the crucified body. Thus, what remains (cf. Agamben, Il tempo che resta), that is, the last appointment of man, is a sphere of pure vulnerability and fragility in the exposing of which sounds an amicable blessing (the grace of Messiah Jesus for all!).

Therefore, the last appointment is neither with a transition to a metaphysical (hidden) world free of suffering, nor with an all-dissolving nothing, but the vision of a new symbolic order (ecce homo!) in which the images in which the powers of history expressed themselves are rendered inoperative, and life rises anew from a fragile encounter. It is an appointment with the irrecoverable which cannot be translated into any image or any language, which "does not entail being remembered and commemorated; rather, it entails remaining in us and with us as forgotten". ${ }^{74}$

This essay shall be closed with essay with one more quote from Agamben: "The messiah comes for our desires. He separates them from images in order to fulfil them. Or rather, in order to show they have already been fulfilled."75

\section{Bibliography}

\section{Secondary Literature}

Agamben, Giorgio. Homo sacer I. Sovereign Power and Bare Life. Translated by Daniel HellerRoazen. Stanford: Stanford University Press, 1998 [Homo sacer. Il potere sovrano e la nuda vita, Torino: Einaudi, 1995].

Agamben, Giorgio. Remnants of Auschwitz. The Witness and the Archive Homo sacer III. Translated by Daniel Heller-Roazen. New York: Zone Books, 1999 [Quel che resta di Auschwitz. L'archivio e il testimone. Homo sacer, III. Torino: Bollati Boringhieri, 1998].

Agamben, Giorgio. State of Exception. Homo sacer, II.1. Translated by Kevin Attell. Chicago: University of Chicago Press, 2005 [Stato di Eccezione. Homo sacer, II.1, Torino: Bollati Boringhieri, 2003].

Agamben, Giorgio. The Time that Remains. A Commentary on the Letter to the Romans. Translated by Patricia Dailey. Stanford: Stanford University Press, 2005 [II tempo che resta. Un commento alla "Lettera ai romani". Torino: Bollati Boringhieri, 2000].

Agamben, Giorgio. The Coming Community (Theory Out of Bounds) 5th ed. Translated by Michael Hardt. Minneapolis: University of Minnesota Press, 2007 [La comunità che viene. Torino: Einaudi, 1990].

Agamben, Giorgio. Profanations. Translated by Jeff Fort. New York: Zone Books, 2007 [Profanazioni. Roma: Nottetempo, 2005].

74 Agamben, The Time that Remains, 40.

75 Agamben, Profanations, 54. 
Agamben, Giorgio. Nudities. Translated by. David Kishik and Stefan Pedatella. Stanford: Stanford University Press, 2011 [Nudità. Roma: Nottetempo, 2009].

Agamben, Giorgio. The Kingdom and the Glory. For a Theological Genealogy of Economy and Government. Homo sacer, II.2. Translated by Lorenzo Chiesa and Matteo Mandarini. Stanford: Stanford University Press, 2011 [/l regno e la gloria. Per una genealogia teologica dell'economia e del governo. Homo sacer, II.2, Vicenza: Neri Pozza, 2007].

Agamben, Giorgio. The Sacrament of Language. An Archaeology of the Oath. Homo sacer II.3. Translated by Adam Kotsko. Stanford: Stanford University Press, 2011 [Il sacramento del linguaggio. Archeologia del giuramento. Homo sacer, II.3, Roma-Bari: Laterza, 2008].

Agamben, Giorgio. The Church and the Kingdom. Translated by Leland de la Durantaye. Kolkata: Seagull Books, 2012 [La Chiesa e il Regno. Roma: Nottetempo, 2010].

Agamben, Giorgio. Opus Dei. Archeologia dell'ufficio. Homo sacer, Il.5. Torino: Einaudi, 2012.

Agamben, Giorgio. The Highest Poverty: Monastic Rules and Form-of-Life. Translated by Adam Kotsko. Stanford: Stanford University Press, 2013 [Altissima povertà. Regole monastiche e forma di vita. Homo sacer, IV.1. Vicenza: Neri Pozza, 2011].

Agamben, Giorgio. Stasis: Civil War as a Political Paradigm. Homo Sacer, II.2. Translated by Nicholas Heron. Stanford: Stanford University Press, 2015 [Stasis. La guerra civile come paradigma politico. Homo sacer, II.2. Torino: Bollati-Boringhieri, 2015].

Agamben, Giorgio. The Use of Bodies. Translated by Adam Kotsko. Stanford: Stanford University Press, 2016 [L'uso dei corpi. Homo sacer, IV.2. Vicenza: Neri Pozza, 2014].

Appel, Kurt. “'Nur in der Geschichte der Zeugen kann Gott in seinem Christus geschichtlich wahr werden'. Die messianische Gemeinschaft und der Homo sacer im Zeugnis von Giorgio Agamben und Johann Reikerstorfer." In Dem Leiden ein Gedächtnis geben. Thesen zu einer anamnetischen Christologie, edited by Kurt Appel, Johann Baptist Metz, Jan Heiner Tück, 281301. Vol. 4, Wiener Forum für Theologie und Religionswissenschaft. Göttingen: V\&R unipress, 2012.

Appel, Kurt. “Gott - Mensch - Zeit: Geschichtsphilosophisch-theologische Erwägungen zu Christentum und Neuem Humanismus im Ausgang von Bibel, Hegel und Musil." In: Preis der Sterblichkeit: Christentum und Neuer Humanismus, edited by Kurt Appel, 19-60. Freiburg i. Br.: Herder, 2015.

Appel, Kurt. "Die Wahrnehmung des Freundes in der Messianität des Homo sacer." In Das Testament der Zeit. Die Apokalyptik und ihre gegenwärtige Rezeption, edited by Kurt Appel and Erwin Dirscherl, 77-111. Vol. 278, Quaestiones Disputatae. Freiburg: Herder, 2016.

Bahr, Hans-Dieter. Die Sprache des Gastes. Eine Metaethik. Leipzig: Reclam, 1994.

Bahr, Hans-Dieter. Zeit der Muße - Zeit der Musen. Tübingen: Attempto Verlag, 2008.

Biguzzi, Giancarlo. Apocalisse nuova version, introduzioine e commento. Vol. 20, I libri bliblici. Milan: Paoline, 2005.

Deibl, Jakob Helmut. "Vom Namen Gottes und der Eröffnung neuer Sprachsäume: Theologischsprachkritische Erwägungen im Ausgang von Bibel, Hölderlin und Rilke.” In: Preis der Sterblichkeit: Christentum und Neuer Humanismus, edited by Kurt Appel, 61-125. Freiburg i. Br.: Herder, 2015.

Dohmen, Christoph. Exodus 19-40 (HThKAT). Freiburg: Herder, 2004.

Hegel, Georg Wilhelm Friedrich. On Christianity. Early Theological Writings. Translated by Thomas M. Knox. New York: Harper \& Brothers, 1948.

Hegel, Georg Wilhelm Friedrich. Phenomenology of Spirit. Translated by A. V. Miller. Oxford: Oxford University Press, 1977.

Heidegger, Martin. Sein und Zeit. Tübingen: Niemeyer, 1927 [Being and Time. Translated by John Macquarrie and Edward Robinson. London: SCM Press, 1962].

Horn, Eva. Zukunft als Katastrophe. Frankfurt/Main: Fischer, 2014. 
Kant, Immanuel. Groundwork for the Metaphysics of Morals. Translated by Allen W. Wood. New Haven, London: Yale University Press, 2002.

Kantorowicz, Ernst. The King's Two Bodies. A Study In Medieval Political Theology. Princeton: Princeton University Press, 1957.

Müller, Martin. "Das Paradigma der Schwelle. Rekapitulation, Interpretation und Anwendung des Denkmodells Giorgio Agambens und seine Relevanz als Perspektive für die politische Theorie." PhD diss., University of Vienna, 2011.

Paulsen, Thomas. "Zu Sprache und Stil des Johannes-Evangeliums." In Poetik und Intertextualität der Johannesapokalypse, edited by Stefan Alkier, Thomas Hieke, Tobias Nicklas, 3-26. Tübingen: Mohr-Siebeck, 2015.

Schwienhorst-Schönberger. Ludger, "Sehen im Nicht-Sehen. Mose auf dem Berg Sinai." In Gottes Wahrnehmungen. Helmut Utzschneider zum 60. Geburtstag, edited by Stefan Gehrig and Stefan Seiler, 102-122. Stuttgart: W. Kohlhammer, 2009.

Zolles, Christian. Die symbolische Macht der Apokalypse: Eine kritisch-materialistische Kulturgeschichte politischer Endzeit. Vol. 2, Cultural History of Apocalyptic Thought. Berlin: De Gruyter, 2016. 